\title{
Use of Sephadex column chromatography in the assessment of thyroid status
}

\author{
T. M. D. GIMLETTE \\ From the Radio-Isotope Laboratory, St. Thomas's Hospital, London
}

SYNOPSIS A method is described for assessing thyroid status using Sephadex column chromatography of serum samples with added ${ }^{125}$ I triiodothyronine. The method is simple and inexpensive. It gave a correct diagnostic result in $97 \%$ of 258 euthyroid, $90 \%$ of 80 hyperthyroid, $78 \%$ of 59 工 hypothyroid, and $67 \%$ of 50 euthyroid, ill patients.

The principle of the method and its limitations are briefly discussed.

Since the red cell uptake of ${ }^{131} \mathrm{I}$-labelled triiodothyronine was introduced as a test of thyroid status (Hamolsky, Stein, and Freedberg, 1957) the technique has been widely used and extensively studied and modified by various workers. There are certain disadvantages in the use of the red cells as an indicator of plasma-binding power for triiodothyronine: these include the possibility of variation in the binding power of the red cells, the rather tedious washing procedure involved, and the fragile nature and poor keeping properties of whole blood samples. A search for a test employing the same principle but a more satisfactory indicator has therefore ensued. Ion exchange resin has been introduced as the indicator (Mitchell, 1958) and there have been various modifications of this technique. The results have been satisfactory but considerable care over quantities and technique is essential in order to get reliable results. The procedure has been simplified by the introduction of resin-impregnated sponges (Mitchell, Harden, and O’Rourke, 1960) but these are expensive. In 1962 Shapiro and Rabinowitz described a chromatographic method using Sephadex columns as the indicator, but the technique involved the counting of large numbers of eluate fractions for each estimation. A modification of this technique is described here, by which only two eluate fractions need to be counted, and it is simple, robust and inexpensive.

When radioiodinated triiodothyronine is added to serum the total radioactivity present may be separated by Sephadex column chromatography into three fractions, namely, protein-bound tri-

'Present address: Department of Nuclear Medicine, The Liverpool Clinic, 1 Myrtle St., Liverpool 7.

Received for publication 18 August 1966. iodothyronine, iodide, and 'free' triiodothyronine. Such a serum placed on a Sephadex column yields protein-bound hormone in the first eluates, radioiodide in subsequent eluates, and 'free' hormone remains in the column but can be eluted almost completely by a further addition of serum to the column (Shapiro and Rabinowitz, 1962; Cuarón and Fucugauchi, 1964). The number of eluate fractions and the completeness of separation of the three constituents depend on the dimensions of the column and the volumes of serum and buffer added to it. Preliminary experiments were carried out to determine the simplest way to estimate the proportions of free and bound triiodothyronine in serum samples.

\section{METHODS}

PREPARATION OF SEPHADEX COLUMNS Pyrex G2 microfilters were used, of nominal external diameter $13 \mathrm{~mm}$. and length $12.5 \mathrm{~cm}$., and measured internal diameter $11.0 \pm 0.2 \mathrm{~mm}$. Sephadex G25, medium grade (Pharmacia Corp.), was mixed with $\mathrm{M} / 15$ phosphate buffer, $p \mathrm{H} 7 \cdot 4$, and introduced into the microfilters to give $\frac{7}{0}$ columns exactly $6 \mathrm{~cm}$. long after washing with more phosphate buffer and settling. Then $4 \mathrm{ml}$. of buffer was $N$ carefully pipetted on to the top of the columns and the level of the top of the buffer solution was marked indelibly on the outside of the microfilters, so that it was possible subsequently to add $4 \mathrm{ml}$. of buffer directly to the columns from a polythene wash bottle. The columns thus prepared can be used repeatedly without change in their properties. They were prepared afresh about $\&$ once a month, since they tend to become slow-running after long use.

PREPARATION OF SERUM SAMPLES Triiodothyronine ${ }^{125}$ I was obtained from the Radiochemical Centre every three months and a stock solution was prepared each week by adding about $0.05 \mathrm{ml}$. to $4 \mathrm{ml}$. of $4 \%$ human albumin. 
This gave a concentration of approximately $0.0015 \mu \mathrm{g}$. of triiodothyronine per millilitre with a specific activity of 0.06 to $0.3 \mu \mathrm{g} . / \mu \mathrm{c}$. The solution was further diluted if necessary with phosphate buffer so that when 1 drop $(0.03 \mathrm{ml}$.) was added to $1 \mathrm{ml}$. of serum this gave a concentration of less than $0.3 \mu \mathrm{g} . / 100 \mathrm{ml}$. of added triiodothyronine and approximately 20 to $40 \mathrm{~m} \mu \mathrm{c}$. of radioactivity. The serum, with added triiodothyronine, was allowed to equilibrate at room temperature for 20 minutes.

PROCEDURE Exactly $1 \mathrm{ml}$. of serum with added ${ }^{125} \mathrm{I}$ triiodothyronine was pipetted on to the column and allowed to enter it; the resultant $1 \mathrm{ml}$. of eluate was discarded. Then $4 \mathrm{ml}$. of $\mathrm{M} / 15$ phosphate buffer was added to the column from a wash bottle up to the previously made mark on the microfilter, and the resultant $4 \mathrm{ml}$. of eluate was collected in a test tube; this contains proteinbound triiodothyronine. The rate of elution was found not to alter the results (see Table IV). Again $4 \mathrm{ml}$. of buffer was added to the column and the $4 \mathrm{ml}$. eluate, which contains iodide, was normally discarded, but was occasionally collected and counted as a check. One ml. of pooled serum was then pipetted on to the column and the eluate discarded. A further $4 \mathrm{ml}$. of buffer was added and the eluate collected; this contains 'free' triiodothyronine which has been adsorbed on to the Sephadex. The two eluates from each column containing bound and 'free' triiodothyronine were then counted in a well scintillation counter.

Calculation of Results The distribution of a small tracer dose of radioactive triiodothyronine added to serum may be described by expressing the quantity of 'free' triiodothyronine as a fraction of the protein-bound triiodothyronine: this is the ' $\mathrm{T}_{3}$-binding coefficient' (Adams, Specht, and Woodward, 1960) in the Sephadexserum system under the given experimental conditions.

$$
\begin{gathered}
\begin{array}{c}
\text { Counts in last } 4 \mathrm{ml} \text {. eluate } \\
\text { Counts in first } 4 \mathrm{ml} \text {. eluate }
\end{array}=\frac{\text { 'Free' } T_{3}}{\text { Bound } \mathrm{T}_{3}} \\
=\mathrm{T}_{3} \text {-binding coefficient }
\end{gathered}
$$

\section{PRELIMINARY EXPERIMENTS AND RESULTS}

In order to decide the best way of using the Sephadex columns and evaluate their properties, certain preliminary experiments were carried out.

1 OPTIUM LENGTH FOR SEPHADEX COLUMNS Serum samples $\left(1 \mathrm{ml}\right.$.) with added ${ }^{125} \mathrm{I}$-triiodothyronine were prepared as described above and pipetted on to Sephadex columns of carefully adjusted height. As the serum entered the top of the column, $1 \mathrm{ml}$. of eluate was collected from the bottom and counted in a well scintillation counter. After the serum had entered the column, $1 \mathrm{ml}$. volumes of buffer were pipetted on to the column and each corresponding $1 \mathrm{ml}$. of eluate was collected and counted until only minimal radioactivity was detectable. Then $1 \mathrm{ml}$. of pooled normal serum without added triiodothyronine was pipetted on to the column and followed by $1 \mathrm{ml}$. volumes of buffer until the eluate again contained minimal radioactivity. This procedure was carried out with columns 5.0, 6.0, and $7.0 \mathrm{~cm}$. in height using two different samples of serum, $A$ and $B$ (Table I). The figures give the percentage of the total activity recovered in each $1 \mathrm{ml}$. eluate.

\section{TABLE I}

\begin{tabular}{|c|c|c|c|c|c|c|c|}
\hline \multirow{3}{*}{\multicolumn{2}{|c|}{ Eluate $(1 \mathrm{ml}$.) following }} & \multicolumn{6}{|c|}{ Height of Sephadex Column } \\
\hline & & \multicolumn{2}{|c|}{$5 \mathrm{~cm}}$. & \multicolumn{2}{|l|}{$6 \mathrm{~cm}$. } & \multicolumn{2}{|c|}{$7 \mathrm{~cm}$. } \\
\hline & & \multirow{2}{*}{$\frac{A}{0.0}$} & \multirow{2}{*}{$\begin{array}{l}B \\
0.0\end{array}$} & \multirow{2}{*}{$\begin{array}{l}A \\
0.0\end{array}$} & \multirow{2}{*}{$\begin{array}{l}B \\
0.0\end{array}$} & \multirow{2}{*}{$\frac{A}{0.0}$} & \multirow{2}{*}{$\begin{array}{l}B \\
0.0\end{array}$} \\
\hline 1 & Serum sample & & & & & & \\
\hline 2 & Buffer & $3 \cdot 0$ & 2.5 & 1.5 & $1 \cdot 1$ & 0.0 & 0.0 \\
\hline 3 & Buffer & $60 \cdot 3$ & $64 \cdot 0$ & $34 \cdot 2$ & 32.6 & 5.8 & 7.2 \\
\hline 4 & Buffer & $19 \cdot 2$ & $22 \cdot 4$ & $40 \cdot 1$ & $48 \cdot 4$ & $48 \cdot 3$ & $51 \cdot 6$ \\
\hline 5 & Buffer & $2 \cdot 4$ & $2 \cdot 3$ & $7 \cdot 4$ & $7 \cdot 6$ & $24 \cdot 3$ & $27 \cdot 4$ \\
\hline 6 & Buffer & $2 \cdot 7$ & $2 \cdot 4$ & 0.8 & 0.8 & $2 \cdot 6$ & $3 \cdot 2$ \\
\hline 7 & Buffer & $1 \cdot 3$ & 1.0 & 0.9 & 0.7 & 0.7 & 0.6 \\
\hline 8 & Buffer & 0.3 & 0.2 & 1.9 & 1.9 & $1 \cdot 1$ & 0.9 \\
\hline 9 & Buffer & 0.1 & 0.1 & 1.4 & $1 \cdot 1$ & 2.2 & $2 \cdot 1$ \\
\hline 10 & Buffer & 0.1 & 0.1 & 0.4 & 0.2 & $1 \cdot 3$ & 0.8 \\
\hline 11 & Pooled serum & 0.1 & $0 \cdot 1$ & $0 \cdot 1$ & $0 \cdot 1$ & 0.5 & 0.4 \\
\hline 12 & Buffer & 3.4 & $2 \cdot 4$ & 0.6 & 0.5 & 0.2 & $0 \cdot 1$ \\
\hline 13 & Buffer & $6 \cdot 2$ & $2 \cdot 4$ & 6.9 & 3.4 & $6 \cdot 4$ & $2 \cdot 4$ \\
\hline 14 & Buffer & 0.8 & $0 \cdot 1$ & $3 \cdot 4$ & 1.4 & 5.9 & $2 \cdot 8$ \\
\hline 15 & Buffer & 0.1 & 0.0 & 0.3 & 0.2 & 0.4 & 0.4 \\
\hline 16 & Buffer & 0.0 & 0.0 & $0 \cdot 1$ & 0.0 & $0 \cdot 1$ & $0 \cdot 1$ \\
\hline
\end{tabular}

OPTIMUM LENGTH OF SEPHADEX COLUMN

From these results it is apparent that $5 \mathrm{~cm}$. columns do not separate adequately the iodide fraction (about $4 \%$ ) from the protein-bound fraction. Columns of 6 and $7 \mathrm{~cm}$. separate all three fractions satisfactorily and $6 \mathrm{~cm}$. columns do so with a smaller volume of eluate, so this size was selected for routine use. The longer the column, the greater the proportion of triiodothyronine that it binds. The size of the iodide fraction was checked from time to time; it varied from $3.2 \%$ to $6.2 \%$ and tended to increase with older samples of ${ }^{125}$ I-triiodothyronine, but it did not vary appreciably with different columns at the same time or with different serum samples. The whole procedure of counting $1 \mathrm{ml}$. fractions was repeated occasionally and when fresh columns were made up, to check that they were functioning satisfactorily.

2 COMPLETENESS OF ELUTION The completeness of elution of activity from the columns by the pooled serum was tested in three ways:

(a) Total recovered activity in the eluates was compared with the initial activity in the sample serum. Recovered activity $=100.02 \% \pm 1.50$ of initial activity (mean of eight experiments).

(b) Recovery after a second elution of the columns with pooled serum was $<0.4 \%$ (five experiments). 
(c) Sephadex was scooped out of the microfilter after completion of the routine procedure and counted in the well counter. Activity remaining in the Sephadex was $<0.4 \%$ (four experiments).

It was concluded that elution of the activity was virtually complete.

3 REPRODUCIBILITY Duplicate and triplicate estimations of the binding coefficient on the same serum gave a coefficient of variation of $4.1 \%$ on 40 different samples (Table II).

TABLE II

RESULTS OF ESTIMATION OF TRIIODOTHYRONINE-BINDING COEFFICIENT IN DUPLICATE AND TRIPLICATE Sample

No.

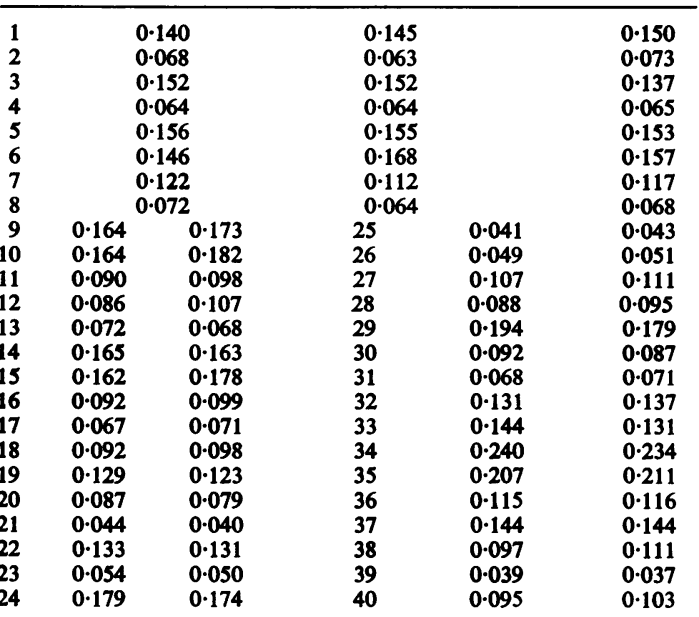

4 EFFECT OF TEMPERATURE The effect of temperature was studied by passing serum and buffer through Sephadex columns at $12^{\circ} \mathrm{C}$. and $34^{\circ} \mathrm{C}$. and at room temperature $\left(21^{\circ} \mathrm{C}\right.$.). This was done with seven different sera. The mean values for the triiodothyronine-binding coefficient are given, with the percentage of the value at room temperature in brackets, in Table III.

TABLE III

EFFECT OF TEMPERATURE ON $\mathrm{T}_{3}$-BINDING COEFFICIENT

\begin{tabular}{cl} 
Temperature $\left({ }^{\circ} \mathrm{C}.\right)$ & $T_{3}$-binding Coefficient \\
\hline 12 & $0 \cdot 078(90 \%)$ \\
21 & $0 \cdot 087(100 \%)$ \\
34 & $0 \cdot 103(118 \%)$
\end{tabular}

Triiodothyronine-binding coefficient increased somewhat over $1 \%$ for each rise of $1{ }^{\circ} \mathrm{C}$. temperature, so that the error was small when the laboratory temperature did not vary more than $2^{\circ} \mathrm{C}$. above or below a mean of $22^{\circ} \mathrm{C}$. If greater variations occur it is necessary to control the temperature of the columns, or to calibrate the binding coefficient for temperature. Under such circumstances it is probably better, however, to calculate the binding coefficient of the sample sera as a percentage of that of a sample of pooled normal serum run under identical conditions, as many workers do when using resin techniques.

5 EFFECT OF VARYING THE VOLUME OF THE TEST SERUM This was studied without changing any other part of the procedure. The volume of serum, whether diluted with saline to make it up to $1 \mathrm{ml}$. or used neat, showed a direct linear relationship (Fig. 1) with the relative binding power of the plasma proteins (the reciprocal of the Sephadex-binding coefficient).

Small volumes of serum can be used with valid results after appropriate correction, but pipetting error is likely to be increased, and $1 \mathrm{ml}$. was found suitable for routine use.

6 EFFECT OF VARYING DURATION OF TEST SERUM IN COLUMN Duration of serum in the column was varied by allowing test sera to remain in the column for half and one hour periods before elution, but this made no difference to the results. Variation in the rate of elution of the protein-bound fraction, and the use of old and fresh Sephadex columns also made no difference to the results (Table IV).

7 EFFECT OF ADDING TRIIODOTHYRONINE TO TEST SERUM The addition of stable triiodothyronine to

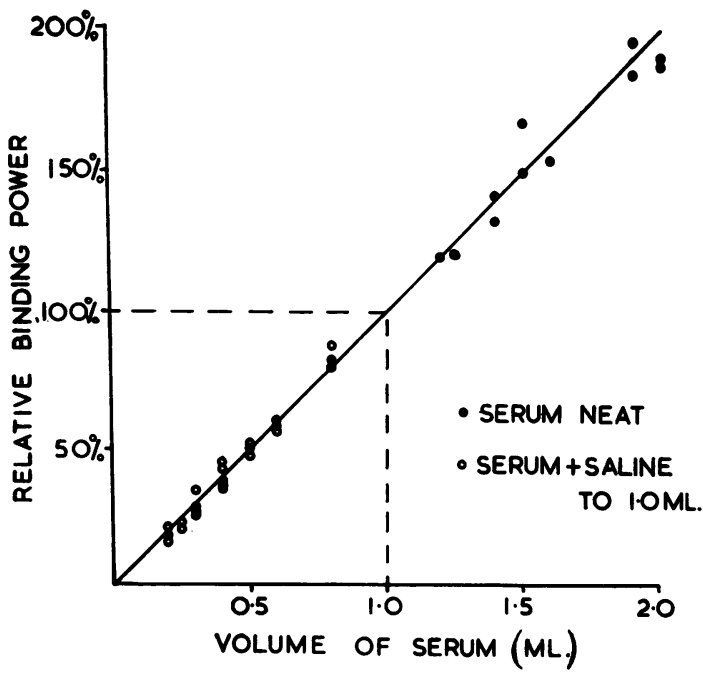

FIG. 1. Relative binding power, expressed as a percentage of that for a sample of $1 \mathrm{ml}$. serum, plotted against volume of serum. $=$ neat serum; $\bigcirc=$ serum + saline to $1 \mathrm{ml}$. 
TABLE IV

VARIATIONS OF ELUTION TIME AND COMPARISON OF OLD AND FRESH SEPHADEX COLUMNS

\begin{tabular}{cccl} 
Serum & $\begin{array}{l}\text { Elution Time } \\
\text { (min.) }\end{array}$ & Binding Coefficient & \multicolumn{1}{c}{ Mean } \\
\hline A & 23 & 0.080 & \\
A & 19 & 0.082 & Slow \\
A & 17 & 0.084 & 0.82 \\
A & 15 & 0.078 & \\
A & 14 & 0.079 & Fast \\
A & 11 & 0.088 & \\
B & 17 & 0.171 & \\
B & 10 & 0.193 & \\
C & 19 & 0.095 & \\
C & 11 & 0.087 & \\
D & 13 & 0.102 & \\
D & 10 & 0.097 & \\
D & 11 & 0.092 & Fresh \\
D & 15 & 0.092 & 0.097 \\
D & 17 & 0.098 & \\
D & 21 & 0.098 & 0.096 \\
& & &
\end{tabular}

TABLE V

EFFECT OF ADDING TRIODOTHYRONINE

\begin{tabular}{|c|c|c|c|c|c|}
\hline \multirow{2}{*}{$\begin{array}{l}\text { Serum } \\
\text { Sample }\end{array}$} & \multicolumn{5}{|c|}{ Stable Triiodothyronine Added ( $\mu \mathrm{g} . / 100 \mathrm{ml})}$. \\
\hline & 0 & 1 & 2 & 4 & 10 \\
\hline $\begin{array}{c}\mathbf{P} \\
\mathbf{Q} \\
\mathbf{R} \\
\mathbf{S} \\
\mathbf{T} \\
\mathbf{U} \\
\text { Mean }\end{array}$ & $\begin{array}{l}0.076 \\
0.081 \\
0.146 \\
0.046 \\
0.097 \\
0.075 \\
0087\end{array}$ & $\begin{array}{l}0.082 \\
0.079 \\
0.150 \\
0.048 \\
0.093 \\
0.077 \\
0.087\end{array}$ & $\begin{array}{l}0.075 \\
0.079 \\
0.173 \\
0.049 \\
0.093 \\
0.085 \\
0.092\end{array}$ & $\begin{array}{l}0.086 \\
0.090 \\
0.193 \\
0.050 \\
0.107 \\
0.084 \\
0.102\end{array}$ & $\begin{array}{r}0 \cdot 100 \\
0 \cdot 100 \\
- \\
- \\
- \\
-\end{array}$ \\
\hline
\end{tabular}

serum before chromatography in quantities to give up to $2 \mu \mathrm{g} . / 100 \mathrm{ml}$. added triiodothyronine was ordinarily without significant effect on the binding coefficient. (In unpublished studies using the red cell $\mathbf{T}_{3}$-binding coefficient it was found that in sera already giving exceptionally high values a just significant increase might occur with the addition of $1 \mu \mathrm{g} . / 100 \mathrm{ml}$. of stable triiodothyronine.)

\section{RESULTS}

The results with this technique in 448 patients are summarized in Figure 2. All the patients studied were referred for assessment of thyroid status and the diagnosis was confirmed by the usual routine methods, including radioiodine studies. The 258 euthyroid patients were not, so far as could be determined, suffering from any serious organic disease; the 51 euthyroid but ill patients were suffering from a variety of conditions of which heart failure was the commonest; 80 patients were hyperthyroid and 59 were hypothyroid. None of the patients were pregnant or on ovulation suppressant or salicylate therapy.

The results are given in terms of the triiodothyronine-binding coefficient for Sephadex since this gives values which can readily be compared with

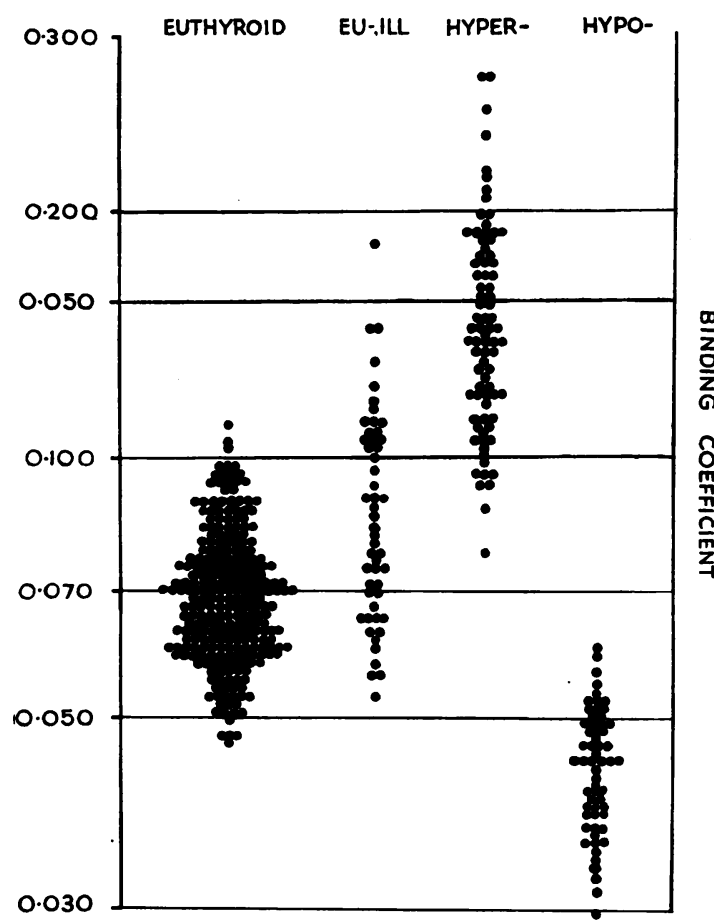

FIG. 2. Triiodothyronine-binding coefficient for Sephadex in four groups of patients.

those obtained in similar tests using the red cells (Adams et al., 1960). The values obtained in the euthyroid patients are not quite normally distributed; the normal range has been taken to be 0.050 to $\mathbf{0} \cdot 100$. Assessment in hyperthyroidism is clearly better $(90 \%$ correct) than in hypothyroidism $(78 \%$ correct). Assessment is least successful in ill patients $(67 \%$ correct $)$; in such patients a value within the normal range is likely to be a correct index of euthyroidism but a raised value is inconclusive.

\section{DISCUSSION}

In the technique described here the triiodothyroninebinding coefficient expresses the binding power of Sephadex relative to that of the binding proteins in the serum. Since the binding power of Sephadex is assumed to remain constant under unchanging experimental conditions, the procedure gives a means of comparing the relative binding power of different sera, and this is proportional to the capacity of unfilled binding sites available (Myant and Osorio, 1959). When different volumes of the same serum are compared, the binding power has been shown to be proportional to the volume used (Fig 1). At any given level of binding protein the 
capacity of unfilled binding sites varies inversely with the free fraction of the total thyroxine (Robbins and Rall, 1960). The estimation of $T_{3}$-binding coefficient thus gives a value which is proportional to the free fraction of total thyroxine. This would give a very satisfactory index of thyroid status if there were no variation in the total capacity of the binding proteins in different individuals. In practice, a decrease in total binding capacity of the proteins leads to a decrease in unfilled binding capacity and hence an increase in triiodothyronine-binding coefficient, or vice versa, which does not reflect a corresponding change in the absolute level of free thyroxine, or thyroid status, and can cause misleading results. The procedure described does nevertheless give a useful indication of thyroid status, particularly if the results in ill patients, in $\underline{\vec{\partial}}$ whom the binding proteins are frequently abnormal, are regarded with reserve, or preferably if the pro- $\overline{\overrightarrow{0}}$ cedure is combined with the estimation of plasmat thyroxine or chemical protein-binding iodine (Gimlette, 1967).

\section{REFERENCES}

Adams, R., Specht, N., and Woodward, I. (1960). J. clin. Endocr., 20, پِ 1366.

Cuarón, A., and Fucugauchi, M. E. (1964). Acta endocr. (Kbh.), 46, $\vec{\circ}$ 161.

Gimlette, T. M. D. (1967). J. clin. Path. In the press.

Hamolsky, M. W., Stein, M., and Freedberg, A. S. (1957). J. clin. Endocr., 17, 33.

Mitchell, M. L. (1958). Ibid., 18, 1437.

, Harden, A. B., and O'Rourke, M. E. (1960). Ibid., 20, 1474. Myant, N. B., and Osorio, C. (1959). J. Physiol. (Lond.), 146, 344

Robbins, J., and Rall, J. E. (1960). Physiol. Rev., 40, 415.

Shapiro, B., and Rabinowitz, J. L. (1962). J. nucl. Med., 3, 417. 